\title{
Instruments and methods of state regulation of the fuel and energy complex
}

\author{
Margarita Agafonova ${ }^{1,}$, , Andrey Chugunov ${ }^{1}$, Elena Bautina $^{1}$, and Oleg Shalnev ${ }^{1}$ \\ ${ }^{1}$ Voronezh State Technical University, Moscovskiy prospect, 14, Voronezh, 394026, Russia
}

\begin{abstract}
The conducted research consists in the possibility of using the obtained data to build a modern model of state regulation of the fuel and energy complex. The research results can be used in the activities of interested state authorities, mainly at the federal level. The paper discusses the theoretical features of state regulation of the fuel and energy complex. The characteristic of the development of the fuel and energy complex of the Russian Federation is given. The paper studies the development of state regulation mechanisms in the fuel and energy complex of the Russian Federation. The problems of development of the fuel and energy complex of the Russian Federation are highlighted. Recommendations for improving interaction between the fuel and energy complex and the state are given.
\end{abstract}

\section{Introduction}

In the modern world of market economy development, interaction between the state and various sectors of the economy plays a special role. Thus, one of the most important aspects of the development of public-private partnership is the fuel and energy complex. This is caused by the fact that the fuel and energy complex plays a strategically important role for the state and affects the degree of development of the economy and national security.

The relevance of the chosen topic lies mainly in the fact that the development and state regulation of the fuel and energy complex is of a strategic nature for the state.

There are two sides to understanding the problem of state intervention in the activities of economic sectors: scientific and public opinion. In fact, the scientific side is, in most cases, the opinion of the state, and the opinion of the public is the opinion of the private sector itself [1]. This issue is relevant in the light of recent economic events. Thus, the development of national production, especially in the field of the fuel and energy complex (hereinafter referred to as FEC), takes its development vector to the domestic market, while not forgetting about the export side of the issue. The balance between the two opposite directions is the main goal of public-private partnership in the fuel and energy sector. Therefore, the problem of achieving this balance and the lack of a solution to the issue is the argumentation of the relevance of the topic under study.

\footnotetext{
* Corresponding author: agaf-econ@yandex.ru
} 
The object of the research is the fuel and energy complex of Russia, the subject is the peculiarities of state regulation in the fuel and energy complex of Russia.

Research hypothesis - it is assumed that the Russian fuel and energy complex has large reserves and opportunities for enhancing investment activities and economic growth. At present, the regulatory role of the state in the fuel and energy complex is decreasing. Meanwhile, the building of business, mutually beneficial relations between the fuel and energy complex and the state is dictated by the national security and geopolitical interests of Russia, the interest of Russian business in creating favorable external and internal conditions for their activities.

The theoretical basis of the research was the domestic and foreign methods of state regulation of the fuel and energy complex.

The methodological basis of this work is caused by the multifaceted nature of the problem under study. The work used theoretical and practical research methods. The theoretical methods include methods of analysis, synthesis, comparison. For practical purposes - the analysis of statistical data.

The informational basis of the research was formed by official materials of the Federal State Statistics Service for the Russian Federation; materials from federal and regional authorities; data published in domestic scientific papers. An important component of the regulatory framework was the Federal Law "On the Electricity Industry", "On Strategic Planning in the Russian Federation".

\section{Materials and Methods}

The fuel and energy complex is a set of sectors of the economy where enterprises are engaged in exploration, development of mineral and other resources that provide the country with fuel and energy. It was revealed that the fuel and energy complex has an important strategic focus for the state: firstly, the internal provision of the state with fuel and energy resources, and secondly, an important component of world trade: in many ways, the prestige of the state in the world market depends on the share of trade in fuel resources (mainly oil and gas) [2].

The main function of the FEC is a district-forming one, since a powerful infrastructure is developing near energy sources, city-forming enterprises are being built. Therefore, a number of problems are being solved: the number of jobs is increasing, nearby cities, towns and villages are developing. However, not everything is so positive in environmental issues, since there are lots of emissions into water bodies and rivers.

The fuel and energy complex is characterized by the presence of a developed industrial infrastructure, which is expressed in trunk pipelines (for transporting oil and gas), as well as the presence of high-voltage power lines.

From the point of view of costs, a balance arises: on average, about $30 \%$ of funds are spent on equipping the FEC. However, the return on the fuel and energy complex is marked by $30 \%$ of the entire industrial complex of Russia [3].

In this area, the issue of the balance of state regulation and market mechanisms is very relevant. According to world experience, the market is able to provide all the necessary tools for the self-development of the fuel and energy complex. However, in modern reality, any market mechanism needs state intervention, especially when it comes to the largest branch of the state.

Thus, the specificity of the fuel and energy complex implies the presence of special mechanisms of state regulation, as well as a special policy strategy in relation to this complex.

So, the fuel and energy complex in its general understanding is a set of enterprises and industries directly related to energy and fuel resources. The fuel and energy complex is 
characterized by the presence of a developed infrastructure, which is quite substantiated: fuel and energy resources must be transported in a particularly technological way to preserve their properties. From the point of view of the state, the fuel and energy complex has a balance of costs and benefits. Also, this complex requires regular innovative changes [4].

\section{Results}

The key components of the fuel and energy complex - the electric power industry and the fuel industry - are closely connected with all sectors of the national economy. Thus, one of the main links of the fuel and energy complex is the transport complex, since the FEC uses metallurgy and mechanical engineering products in its activities. In addition, the most important factor for the fuel and energy complex is the presence of a developed infrastructure - high-voltage trunk lines, pipelines and their unified networks.

However, natural monopolies are under the authority of the Government of the Russian Federation, and it also sets the limit levels of tariffs, considers investment programs, regulates access to gas and oil pipelines, and determines the basic tasks for the supply of products of activity to the domestic market.

The Federal Energy Commission (FedEC) is the executive body of state power that regulates natural monopolies. FedEC, which considers the costs of monopolies, makes proposals for changing tariffs.

The main task of the FedEC is to establish positive relations between the consumer and the energy producer. This balance allows achieving two-way benefits - on the one hand, affordable energy prices for consumers, on the other, the development and normal functioning of the producer. Thus, the main function of the FedEC is to regulate the prices of natural monopolies. Accordingly, regional energy commissions perform this function at the regional level [5].

The range of goods in the energy, oil and gas industry is very small and strictly limited. In this regard, free prices cannot act as an instrument of competition. Because of this, there is a need for government regulation. The state and the tax system, working in tandem, regulate prices in such a way that the financial needs of both energy consumers and producers are taken into account, of course, considering the possibilities.

Today, the fuel and energy complex is especially in need of financial and price control by the state. The importance of the intervention is caused by the fact that domestic energy prices, as well as financial flows that pass through the fuel and energy companies, must be regulated and controlled by the state in order to maintain a balance and benefit to all parties of production and consumption.

One of the most important reasons why government intervention in the price policy of the fuel and energy complex is necessary is protection from sharp fluctuations in world prices and the ruble exchange rate. But this does mean their complete autonomy. In this context, world prices should become a stimulant for the adaptation of domestic producers and consumers.

Excessive fluctuations in the price policy in the world can lead to a negative result and affect the production potential, which will create high barriers to the development of investment activities in this area in the form of high risks.

It is necessary to strive for the level of developed countries, where the relationship between world and domestic prices is direct: they grow together and decrease together. However, the change in domestic prices itself is much less precisely because of government regulation.

Considering that Russia uses most of its energy resources within the state, this issue is most relevant. Thus, the ratio and level of prices for non-energy carriers must necessarily 
depend on the costs of their production, including transportation and capital investment requirements. Global trends show that a significant stimulus contributing to structural changes in the economy is the increase in prices for fuel and raw materials. That is why the fuel and energy complex constantly needs new technologies that lead to maximization of utility while minimizing resource costs. Due to technologies, the structure of production is changing, energy-saving industries are developing, therefore, the consumption of energy carriers and raw materials is decreasing, which, in turn, leads to a trend towards a decrease in world prices for goods.

In order to regulate tariffs in all sectors of the fuel and energy complex, a certain single tariff body is needed. Determining the cost of a rigid economic dependence between the components (gas, fuel, energy, railways) requires serious coordination from the state.

It is in the interests of the state to take responsibility for the regulation of the FEC tariffs. The interest is caused by a simple fact - the state's share in the fuel and energy complex is significant. Thus, the share of the state in the FEC industries amounted to more than $80 \%$ in 2017 .

The state energy saving policy is implemented on the basis of:

- development and implementation of federal, interregional and regional energy supply programs;

- pursuing a structural policy that changes the proportion of products of different energy intensity;

- conducting energy audits of enterprises;

- state expertise of construction projects and creation of demonstration zones of high energy efficiency;

- involvement of unconventional energy sources in the energy balance.

So, among the key methods and instruments of state regulation of the fuel and energy complex in Russia, there are: regulation of the complex by a special executive body, which is called the Federal Energy Commission (FedEC); strengthening of financial and price control of the fuel and energy complex by the state; the FEC objects are checked with the help of the subordinate organization of the Ministry of Energy Gosenergonadzor (State Energy Supervision); a number of economic methods, among which the key one is energy saving management.

\section{Discussions}

Before proceeding to the analysis of the problems of state regulation, it is worth identifying the key areas of the development of the FEC in Russia today.

The main external problems of the development of the world energy sector (and the Russian fuel and energy complex as an integral part of this large system) for the coming decades are as follows:

After 2020, world oil production will reach its maximum level by 2035. This implies an economic breakthrough, not a physical depletion of oil resources. As a result, oil prices on the world market will gradually rise. This trend is spelled out in all forecasts for the development of the world energy

Global warming and the commitment to preserve the planet's climate can have a significant impact on the structure of energy consumption, leading to a reduction in the share of carbonaceous fuels (especially coal) in it.

The energy security policy of the main importers of energy resources is already leading to a decrease in energy imports from regions with an unstable political situation, to the development of their own energy sources. 
There may be restrictions on the development of nuclear power as a result of accidents at Chernobyl and Fukushima [6].

Prospects for the development of world energy are considered when developing the Energy Strategy of Russia until 2035, but our national energy sector has key features and problems. Namely:

Extremely low energy efficiency of the economy;

Weak diversification (expanding the range of products in order to increase production efficiency, obtain economic benefits) of energy resources - 52\% of domestic demand and $42 \%$ of energy production is provided by gas.

Heavy load of the fuel and energy complex on the environment and economy.

The problem of the Russian fuel and energy complex is a much more significant burden on the economy than in the whole world. According to the World Energy Agency, over the past 20 years, the world has invested $1.5 \%$ of total GDP in energy, and it predicts investment in energy at $1.3-1.5 \%$ of GDP by 2030 . These are colossal volumes - 21-22 trillion dollars, but the burden of energy on the economy remains more or less the same. In Russia, according to the forecasts of our scientists, investment in the fuel and energy complex will amount to 6 to $8 \%$ of GDP against $4 \%$, which was actually spent in the last five years. Indeed, this is already the limit of the economy's capabilities.

Thus, among the main problems of the fuel and energy complex are: global warming, energy security policy, investment in the fuel and energy complex.

\section{Conclusion}

Nowadays, the fuel and energy complex is one of the stably operating industrial complexes of the Russian economy. It has a decisive influence on the state and development prospects of the national economy, providing about $25 \%$ of gross domestic product (GDP) production, $30 \%$ of industrial production and revenues of the consolidated budget of Russia, about half of federal budget revenues, exports and foreign exchange earnings [7-9]. Only effective and high-quality state regulation in the development of the economy in general and the fuel and energy complex in particular will ensure the stable and sustainable operation of the fuel and energy complex. In the course of market transformations, the state has shown a certain caution in reforming the fuel and energy complex, and many problems of the FEC remained unresolved. The issue of rational interaction between the state and business in solving these problems remains relevant. The social role of the FEC is of fundamental importance for the state policy in the energy sector.

Among the factors affecting the stability of the functioning of the Russian fuel and energy complex, we will single out the climatic and natural-geographical ones. Russia is the coldest country in the world, with limited access to ice-free ports and limited capacity of transport and energy communications.

The development of energy in Russia, the largest world power, is possible only in an integrated way. Nowadays, the structure of the Russian fuel and energy complex is shifted towards non-renewable sources of hydrocarbons. The list of threats to sustainable fuel and energy supply includes the following:

- potential shortage of energy resources in the domestic market for export needs;

- their irrational and wasteful use;

- unbalanced structure of energy production and export;

- disproportion in fuel and energy supply of certain regions of the country;

- excessive orientation of the FEC and state bodies towards the reproduction of purely raw materials specialization in Russia.

Thus, at present, the regulatory role of the state in the fuel and energy complex is decreasing. Meanwhile, the building of business, mutually beneficial relations between the 
FEC and the state is dictated by the national security and geopolitical interests of Russia, the interest of Russian business in creating favorable external and internal conditions for their activities.

The issues of national and energy security of the state are of particular importance, taking into account the activities of the oil and gas sectors of the economy in the northern regions of Russia, where more than $70 \%$ of Russian energy resources are concentrated, to which both oligarchic groups in Russia itself and foreign corporations pay attention. Only state intervention can stop the redistribution and privatization of northern mineral resources in the interests of the country.

\section{References}

1. O. A. Kutsygina, M. S. Agafonova, A. V. Chugunov, I. A. Serebryakova, Sost management for fuel and energy resources in the creation and operation of urban infrastructure, Advances in Intelligent Systems and Computing, 1258, 553-565 (2021)

2. D. Borisov, A. Sokolova, A. Nikolaeva, Neft' i nefteprodukty: soglasheniya o modernizacii neftepererabatyvayushchih moshchnostej, Izmeneniya $\mathrm{i}$ tendencii $\mathrm{v}$ regulirovanii TEK Rossii i mira, 10 (2018)

3. V mire: Toplivnaya effektivnost' i spros na neft', Energeticheskij byulleten', 61, 23 (2018)

4. A. S. Ovsyannikov, V. A. Bolgov, A. V. Vorotyntseva, A. S. Efimiev, International Scientific Conference Energy Management of Municipal Facilities and Sustainable Energy Technologies EMMFT 2018, 695-703 (2018)

5. A. S. Belaya, Gosudarstvennoe regulirovanie toplivno- energeticheskogo kompleksa kak bazovoj otrasli ekonomiki Rossii, Problemy sovremennoj ekonomiki, 10 (2016) https://cyberleninka.ru/article/n/gosudarstvennoe-regulirovanie-toplivnoenergeticheskogo-kompleksa-kak-bazovoy-otrasli-ekonomiki-rossii (Last accessed 10.11.2020)

6. A. Efim'ev, O. Kucygina, M. Agafonova, A. Chugunov, Tendencii v sfere povysheniya energeticheskoj bezopasnosti, v sbornike: energeticheskoe upravlenie municipal'nymi ob"ektami i ustojchivye energeticheskie tekhnologii. sbornik trudov po materialam XXI Mezhdunarodnoj nauchnoj konferencii, 90-96 (Voronezh, 2020)

7. Investicii v TEK: rost posle krizisa na rynke nefti, Energeticheskij byulleten', 61, 4-13 (2018)

8. T. V. Alesinskaya, D. V. Arutyunova, V. G. Orlova, I. V. Ilin, S. V. Shirokova, Conception BSC for investment support of port and industrial complexes Academy of Strategic Management Journal, 16(1), 10-20 (2017)

9. I. V. Ilin, A. V. Izotov, S. V. Shirokova, O. V. Rostova, A. I. Levina, Method of decision making support for it market analysis Proceedings of 2017 20th IEEE International Conference on Soft Computing and Measurements, SCM 2017, 7970732, 812-814 (2017) 